\title{
Index Lesion
}

National Cancer Institute

\section{Source}

National Cancer Institute. Index Lesion. NCI Thesaurus. Code C110961.

The largest tumor lesion targeted by therapy. 